University of Michigan Law School

University of Michigan Law School Scholarship Repository

Articles

Faculty Scholarship

1917

\title{
A Modern Evolution in Remedial Rights - The Declaratory Judgment
}

\author{
Edson R. Sunderland \\ University of Michigan Law School
}

Available at: https://repository.law.umich.edu/articles/1360

Follow this and additional works at: https://repository.law.umich.edu/articles

Part of the Courts Commons, Legal Remedies Commons, Supreme Court of the United States Commons, and the Torts Commons

\section{Recommended Citation}

Sunderland, Edson R. "A Modern Evolution in Remedial Rights-The Declaratory Judgment." Mich. L. Rev. 16 (1917): 69-89.

This Article is brought to you for free and open access by the Faculty Scholarship at University of Michigan Law School Scholarship Repository. It has been accepted for inclusion in Articles by an authorized administrator of University of Michigan Law School Scholarship Repository. For more information, please contact mlaw.repository@umich.edu. 


\section{MICHIGAN}

\section{LAW REVIEW}

Vor. XVI.

DECEMBER, I9I7

No. 2 .

\section{A MODERN EVOLUTION IN REMEDIAL RIGHTS,-THE DECLARATORY JUDGMENT.}

T $N$ a recent opinion of the Supreme Court of the United States Justice Hormes makes this interesting observation:-

"The foundation of jurisdiction is physical power, although in civilized times it is not necessary to maintain that power throughout proceedings properly begun."

An analysis of this language brings out a double antithesis. There is first proposed a distinction between the existence and the exercise of physical power as the basis of judicial authority. And there is the further suggestion that this distinction, as a practical feature of administrative justice, depends on the presence or absence, which in effect means the degree, of civilization.

To paraphrase Justice HoLmes' statement we therefore have substantially the following proposition:

In early times the basis of jurisdiction is the existence and the constant assertion of physical power over the parties to the action, but as civilization advances the mere existence of such power tends to make its exercise less and less essential.

If this is true, it must be because there is something in civilization itself which diminishes the necessity for a resort to actual force in sustaining the judgments of courts. And it is quite clear that civilization does supply an element which is theoretically capable of entirely supplanting the exercise of force in the assertion of jurisdiction. This is respect for law. If the parties to the action desire to obey the law, a mere determination by the court of their reciprocal rights and duties is enough. No sheriff with his writ of injunction or execution need shake the mailed fist of the State in the faces of the litigants. The judgment of the court merely directs

1 McDonald v. Mabee (Decided March 6, I917), 37 Sup. Ct. Reporter 343. 
the will of the parties, and the performance of duty becomes the automatic consequence of the declaration of right.

It is not to be assumed that the peaceful acquiescence of the highly civilized man in the legal findings of the court implies any loss of power in the court itself. Quite the contrary. The greater the ease with which the court's findings impose themselves on litigants, the more the real power of the court is demonstrated. But the force behind the finding of the court has become a latent instead of an active force. This transition is possible, however, only when the existence of the force is so well recognized and so clearly understood that no one would think it worth while to put it to the test. The entire cessation of actual coercive measures on the part of the court would therefore mark, not the disappearance, but the perfection of the rule of force. ${ }^{2}$

The modern observer, noting this correlation between social progress and the decline in the need for outward display of force in the administration of justice, may well ask himself why we have not done better than we appear to have done. If the existence of force is enough, without its exercise, to sustain the court in its findings, why do we not show a realization of that fact in our remedial machinery? If the power of the state stands irresistibly behind our judicial decisions, why take so much pains to clothe them with the outward show of authority? Why display the sheriff and his writ with so much ostentation? We do not arm our traffic policemen with guns and cutlasses. Why insist that the court must always rattle the sabre?

To make a specific application of this general criticism, let it be asked why our judicial system does not provide a means for merely determining and declaring rights. If our civilization is not a sham, and the state is understood to be equal to the task of enforcing the decrees of its courts, a mere declaration may serve every purpose of an order, and the order will become unnecessary. A declaration by the court that $A$ is entitled to the immediate possession of a chattel in B's possession, should be equally effective in A's behalf as a judgment that $A$ do have and recover of $B$ the possession of the chattel. A judicial declaration that a certain city ordinance is invalid ought to serve equally as well as an injunction against its enforcement. Furthermore, the remedial possibilities in such declaratory judgments are much greater than in judgments for relief, and they open up an entirely new field for judicial usefulness, as will be hereinafter pointed out.

2 Salmond, Jurisprudence, Ed. 4, p. 66. 
The answer to the question, why our courts do not make declarations of right, with or without relief, is probably historical, and lies in the philosophical conceptions of rights and remedies which have long been current in common law jurisprudence.

The common law was wedded to the idea of a wrongful act on somebody's part as a necessary condition precedent to judicial action.

Thus Hol,AND, speaking of remedial rights, or rights of recourse to courts of justice, says :- "The causes, or 'investitive facts,' of remedial rights are always infringements of antecedents rights $* * * " 3^{3}$ And again, he says: "So long as all goes well, the action of the law is dormant. When the balance of justice is disturbed by wrongdoing, or even by a threat of it, the law intervenes to restore, as far as possible, the status quo ante." And in still further emphasis of this same characteristic of the court, as an ex post facto agency, he says:- - If all went smoothly, antecedent, or primary, rights would alone exist. Remedial, or sanctioning, rights are merely part of the machinery provided by the State for the redress of injury done to antecedent rights. This whole department of law is, in an especial sense 'added because of transgressions'."'

SAIMOND expresses the same view as to the function of courts and the conditions under which they may be used by litigants. He says:- "Both in civil and in criminal proceedings there is a wrong (actual or threatened) complained of. For the law will not enforce a right except as against a person who has already violated it, or who has at the least already shown an intention of doing so. Justice is administered only against wrongdoers, in act or in intent.".

One of he most widely quoted analyses of a remedial right, which is merely the right to resort to a court of justice, is that made by Pomeroy, in which he says:- **** Every remedial right arises out of an antecedent primary right and corresponding duty and a delict or breach of such primary right and duty by the person on whom the duty rests. Every judicial action must therefore involve the following elements: a primary right possessed by the plaintiff, and a corresponding primary duty devolving upon the defendant; a delict or wrong done by the defendant which consisted in a breach of such primary right and duty; a remedial right in favor of the plaintiff, and a remedial duty resting on the defendant springing from this delict, and finally the remedy or relief

3 Jurisprudence, Ed. 9, p. 3 10.

- Jurisprudence, p. 306.

5 Jurisprudence, p. 139.

- Jurisprudence, p. 73. 
itself. Every action, however complicated or however simple, must contain these essential elements."'

The foregoing views make no distinction between legal and equitable actions, but treat remedial rights generically.

That the two divisions of the law operate upon the same theory of remedial justice, in respect of the point now under consideration, is quite obvious. Thus, injunctions are granted to restrain threatened wrongs, specific performance is decreed in case of breach of certain contracts, various remedies are available against those who are guilty of fraud or whose claims wrongfully rest on accident or mistake, an accounting may be had to test the accounts of those who are charged to have profited at the plaintiff's expense, titles are quieted against those wrongfully asserting rights hostile to the title of the plaintiff. In the case of bills for discovery, there is usually an action at law to which the bill is ancillary, and furthermore the party against whom the discovery is sought may be deemed to be wrongfully refusing to disclose. In all of these cases coercive relief is granted. A single exception serves only to make the rule more striking, and this is the administrative control exercised by courts of equity over trusts, permitting a resort by the trustee to the court to obtain a judicial construction of his powers and responsibilities under the terms of the trust instrument.

Proof of the accuracy of this summary of the attitude of courts of equity, in accordance with which they refuse to take jurisdiction of cases not calling for coercive relief, may be found in the express language of our courts. Thus in Woods v. Fuller, ${ }^{8}$ the Supreme Court of Maryland said:- "A Court of equity will not take jurisdiction, unless it can afford immediate relief $* * *$ It must be borne in mind that the decree of a Court of equity, and not its opinion, is the instrument through which it acts in granting relief. However sound and clear such opinion may be, as an abstract proposition of law, yet if the principle it declares cannot be carried into effect by a aecree, in the case in which it is given, it is wholly valueless, and an idle and nugatory act."

In Greeley v. Nashua the city of Nashua filed a bill to determine its rights to certain property devised to it under a will, and the Supreme Court of New Hampshire said:- "The plaintiffs $* * *$ request the court to inform them what their legal rights and those of the defendants are in the property devised. The court might with equal propriety be called upon by the parties interested

7 Code Remedies (4th Ed.), Sec. 347.

8 (1884) 6r Md. 457.

( (1882) 62 N. H. 166. 
to advise them regarding the title to land, the construction of a contract, or any other question of law. Such questions are not ordinarily adjudicated until it becomes necessary to decide them in proceedings instituted for the redress of wrongs."

And in Bevans v. Bevans ${ }^{10}$ a bill was filed to obtain the construction of a will with respect to the title to real estate. The Chancellor of New Jersey said:- "*** It is settled that the court will not express opinions in regard to construction for the mere information of parties, disconnected from some equitable relief sought."

In accordance with this view of the defendant as an alleged wrongdoer, and the action as one founded upon his actual or threatened wrong, it is quite true that a judgment for relief against him would always be appropriate, and would fully meet the situation. So the law reasoned, and so it ruled. If coercive relief might always be granted, it ought always to be granted, for why make a mere declaration of right against a wrongdoer who is before the court and subject to its power. Why merely tell him that he has no right to do as he proposes when the court can just as well prohibit the act. Why merely advise when it can as well command?

The United States has, in every department of its legal practice, accepted without question the foregoing theory of remedial justice. We have not allowed our developing civilization, with its constantly increasing respect for law, to produce any effect upon judicial functions. We refuse to allow parties to appear in court except under conditions which permit a display of force by the judicial arm of the state.

England has been much more enterprising. In 1852 parliament took the first step to abandon this archaic conception of remedial law. In that year an act was passed amending the practice of the High Court of Chancery, and one of the sections of that act provided as follows:-

"No Suit in the said Court shall be open to Objection on the Ground that a merely declaratory Decree or Order is sought thereby, and it shall be lawful for the Court to make binding Declarations of Right without granting consequential Relief."11

This statute, while striking in its novelty, was subject to strict limitations. It applied only to Courts of Chancery, and it was construed to embrace only those cases where there was consequential relief which might be granted, but which the parties did not care

${ }^{10}$ (1905) 69 N. J. Eq. I.

11 I5 and 16 Vict., c. 86 , s. 50 . 
to ask for or receive. ${ }^{12}$ It did not authorize anybody who had an apprehension that some day, in the happening of some possible event, another might make a claim against him, to institute a suit to have it declared that there was no ground of claim. ${ }^{13}$ It did not, in other words; authorize a declarator, as this proceeding was used in certain situations under the Scotch law. ${ }^{14}$

But while the act was so closely circumscribed in its operation, the judges did not seem to be entirely agreed that there was any real occasion for so narrow a restriction upon declarations of right. Thus in Jackson v. Turnley" the Vice Chancellor said:- "Now it is urged that it would be extremely convenient, if whenever a party has reason to apprehend that another will make an attack upon him, he should be entitled to come to this Court, and to ask to be relieved from that danger, by having it declared by a decision that there is no such right; $* * *$ nor do I see that from the exercise of it [such a jurisdiction] any mischief could result to the Defendant."

. And in 1876 , in Cox v. Barker, ${ }^{10}$ JAMES, L. J., referring to the cases construing this statute, said that it appeared to him "the Court adopted rather a narrow view $* * *$." But the court never attempted to enlarge the scope of the statute by construction.

But reforms moved swiftly in England. In I873 the Judicature Act completely broke the shackles with which conventionality had burdened the administration of justice. And in the rejuvenation which the law experienced, all the limitations upon declaratory judgments which the old statute had retained, were swept away. The new rule was put into force in 1883 , as Rule 5 of Order 25, and provided as follows:-

"No action or proceeding shall be open to objection, on the ground that a merely declaratory judgment or order is sought thereby, and the Court may make binding declarations of right whether any consequential relief is or could be claimed or not."

This rule introduced "an innovation of a very important kind", to use the words of Justice IIINDLEY. ${ }^{17}$ It threw open to the court the right to do just what the Chancellor of New Jersey declared in Bevans v. Bevans (supra), that courts would never do, namely,

\footnotetext{
12 Rooke v. Lord Kensington (1856), a K. \& J. 753, 76x.

12 Jackson $\nabla$. Turnley (I853), I Drew. 6r7, 627.

11 Rooke จ. Lord Kensington (supra); Grove $\dot{v}$. Bastard, 2 Ph. 6rg; Erskine on the Law of Scotland, $46 x$.

1s Supra, note 13 , at p. 626 .

Is 3 Ch. D. 359, 370 .

17 Ellis v. Duke of Bedford (1899), I Ch. 494, 5r5.
} 
stexpress opinions in regard to construction for the mere information of parties $* * *$."

Later, another rule was added which is probably to be deemed a mere specification of a class of cases originally embraced within the terms of the foregoing rule, which provided in express words that-

"In any Division of the High Court, any person claiming to be interested under a deed, will, or other written instrument, may apply by originating summons for the determination of any question of construction arising under the instrument, and for a declaration of the rights of the persons interested."18

For thirty-five years the English courts have exercised this jurisdiction, both at law and in equity, of advising parties as to their rights, with or without coercive relief at the option of the parties.

Now, two different cases, based upon different principles, are presented by the present English rules.

I. We have first the case where coercive relief might be had, but it is not desired. Here there is merely a new remedial right granted to the plaintiff. He has a cause of action of the conventional type, but he wants to use it for a new purpose. Instead of asking that the defendant be ordered to perform his contract, he only wants the court to assure him and inform the defendant that he has a right to performance. Instead of enjoining the defendant from taking certain action, he merely asks the court to advise him and the defendant whether the latter has a right to take it.

The advantages of asking advice instead of coercive relief are important. In the first place it presents in the pleading a specific and express issue of law, which can usually be answered yes or no and which will settle the controversy between the parties. In this way the scope of the legal inquiry presented by the pleadings is clarified and limited. Furthermore, the issue of law is not one which must, as in case of a demurrer, be developed without any accompanying issue of fact. It is usually an issue of law to be decided upon the outcome of the trial or hearing, so that almost every case is capable of being presented as a case for advice. Thus a declaration of right may be asked as to a contract which plaintiff alleges contains certain provisions. If the defendant denies some of the terms alleged, the declaration of right will be based on the terms which the evidence substantiates. If one were inclined to question the advantage of this procedure in simplifying the issues, a glance through some of the current English reports would convince him of its effect. The question to be decided is always the 
correctness of the declaration asked, and the court has only toanswer the specific questions thus put to it.

By asking for the declaration of right the party makes definite and certain the theory of his case, and the court is never at a loss. to understand exactly what is in issue between the parties.

2. But there is a second result which this procedure accomplishes in cases where coercive relief might be had, and that is a psychological one. Every case may by this means become, in appearance at least, a friendly suit. There is no doubt that the personal animosities developed by litigation are serious drawbacks to the usefulness of the courts. To sue is to fight, and fights makeendless feuds. Parties hesitate to resort to the courts because they shrink from a state of war with their neighbors or business associates. But if the courts could operate as diplomatic instead of belligerent agencies, less hesitation would be felt over recourse to. them, and less strain would be put upon the friendly relations of the parties. To ask the court merely to say whether you have certain contract rights as against the defendant is a very different thing from demanding damages or an injunction against him. When yout ask for a declaration of right only, you treat him as a gentleman. When you ask coercive relief you treat him as a wrongdoer. That is the whole difference between diplomacy and war; the former assumes that both parties wish to do right, the latter is based on: an accusation of wrong. A request for a declaration of right plainly implies full confidence that the defendant will promptly and voluntarily do his duty as soon as the court points it out to him. It indicates a willingness to rely on the defendant's sense of honor, as a sufficient remedy. It makes the law suit a coöperative proceeding, in which the court merely assists the parties to settle their own differences by stating to them the rules of law which govern them.

These considerations alone are enough to recommend the practice in any country where respect for the rights of others is considered a virtue. The force behind the court is not at all weakened by it, for if it appears that the plaintiff's confidence in the defendant's readiness to do right is misplaced, the coercive decree of the court is always ready to be promptly issued in support of its declaration.

An entirely different situation, however, is presented in those cases where no coercive relief can be granted. Here there is an entire absence of a cause of action in the conventional sense. Since the defendant has not yet done or threatened anything wrong, nor failed to do all that is lawfully incumbent upon him, there is noth- 
ing for the court to operate upon, if we accept the definitions of a cause of action set forth in an earlier portion of this article. If remedial rights arise only in support of primary rights infringed or threatened, there can be no remedial right of any kind in such cases.

To account for the right to a declaratory judgment in cases where no relief is possible, it seems necessary to boldly concede that the statute which authorizes it has created not a new remedy merely, but a new primary right. The old primary rights were the correlatives of duties calling for present action on the part of the defendant. These were infringed when the defendant failed to do what the law required. They were all based on a social system which considered justice as a by-product of force, and which saw no need for judicial administration concerning itself with any but wrongdoers. The common law never looked upon the courts as agencies useful for enabling parties to keep out of trouble. That was the business of the lawyers. It never admitted that any one had a legal right to know what his rights were.

The new rule authorizing declaratory judgments in cases where no relief is possible, gives one the right to know his rights. Since ignorance of the law excuses no one, the law will furnish an oracle to declare it. Assuming that parties intend to do right, it will point out the way they should go. To use a homely figure, prior to 1883 the English courts were employed only as repair shops; since that time they have been operated as service stations.

The field which the new rule opens is a wide and fruitful one, and by contrast makes the old practice, which is of course the current American practice, seem incredibly stupid. It furnishes remedies which no civilized country ought to deny to its citizens, and the lack of them is a serious hardship in this country.

The practice of making declarations of right has completely revolutionized English remedial law. The American lawyer who peruses the current English reports is bewildered by their novelty. $\mathrm{He}$ is like a modern Rip Van Winkle, who, having gone to sleep in an age when courts were only the nemesis of wrongdoers, awakens to find that they have become the guardians and advisers of those who respect the law.

The only recourse of an American who wishes to get a forecast of his rights is to consult his lawyer. But the lawyer's opinion is without the slightest binding force. Vast interests may be at stake, but all the client can do is to gamble on the sagacity of his counsel.

In England such compulsory gambling has been outgrown. The 
client consults his lawyer, the lawyer, in case of doubt, frames a case for the court, and the court, on a full hearing with all interested parties before it, makes a final and binding declaration on which the client can act with perfect security. The practice is so convenient and so obviously advantageous that it has become almost a matter of course in English chancery cases and is very common on the law side of the court. An examination of the last volume of Chancery reports, volume 2 for I9I6, shows that out of 64 cases reported, 43 were brought for declarations of right. The advance sheets of the Law Journal, for September, I9I7, show I5 Chancery cases of which I2 were brought for declarations. It would be safe to say that approximately two-thirds of the current Chancery litigation in the Supreme Court of Judicature is directed to obtaining the advice of the court as to rights of litigant parties, with or without prayers for consequential relief.

The cases in the volume of chancery reports above mentioned will illustrate the nature and range of questions put to the court for determination. Thus, in Lovesy v. Palmer, ${ }^{18}$ plaintiff asked for a declaration that certain memoranda and letters constituted a binding contract between the defendants and the plaintiff to make a lease of a theatre. In $S$ mith, Coney \& Barrett v. Becker, Gray $\& C_{0 .}{ }^{20}$ the plaintiff asked for declarations that certain contracts which they had made with defendants were illegal by reason of the proclamation of a state of war between Great Britain and Germany. In $R e$ Lodwig ${ }^{21}$ the plaintiff asked the court to declare, whether certain trusts were void for remoteness. In $R e N e w$ Chinese Antimony Co., Lim., ${ }^{22}$ the liquidator of a company asked the court to determine and declare the correlative rights of the preferred and common shareholders in the assets of the company. In $R e$ Chafer and Randall's Contract ${ }^{23}$ plaintiff asked a declaration that the abstract of title delivered by the defendant to the plaintiff did not show a good title. In Cassel v. Inglis s. $^{24}$ plaintiff asked the court to declare that he had been illegally excluded from membership in the Stock Exchange. In Coleman v. London County and Westminster Bank, Lim., ${ }^{25}$ the court was asked to decide the question of priorities in certain debentures as between the plaintiff and

\footnotetext{
28 Order $54 \mathrm{~A}$, rule $I$, passed in 1893 .

10 (1916) $2 \mathrm{Ch} .233$.

2 (1916) 2 Ch. 86.

21 (1916) $2 \mathrm{Cb}, 26$.

$2(1916)=\mathrm{Ch} .115$.

2 (1916) $2 \mathrm{Ch} .8$.

st (Ig16) $2 \mathrm{Ch}$. $21 \mathrm{r}$.

25 (1916) $2 \mathrm{Ch} .353$.
} 
defendant. In Parsons v. Equitable Investment Co., Lim., ${ }^{28}$ the court was asked to declare that a certain bill of sale was void because it failed to truly state the consideration for which it was given. In Pearce v. Bulteel ${ }^{27}$ a declaration was asked as to who were the owners of certain property. In Gilbert v. Gosport and Alverstoke Urban District Council ${ }^{28}$ plaintiff asked the court to declare that he owned certain land free of any public right of way. In a majority of the above cases there was a present cause of action in the plaintiff, which was either utilized as the basis for a claim for relief in addition to the declaration of rights, or was abandoned in favor of the declaration as a better remedy.

In at least twenty cases in the same volume the court was asked to construe wills or make declarations as to rights acquired under wills, involving such'questions as:-whether certain funds should be paid to a life tenant as income or retained by the trustees as capital, ${ }^{28}$ whether the words "lawful issue" were restricted to children or included remoter descendants, ${ }^{80}$ to what bequests a provision against lapse applied," whether farm laborers were "servants" within the meaning of a bequest, ${ }^{82}$ whether a devise of land was subject to a water pipe easement ${ }^{39}$ and many others, most of them involving, but others not involving, trusts.

The cases where a declaration of rights is the sole possible remedy are not easy to classify. Perhaps no logical classification is possible, for the whole matter of declaratory judgments is discretionary with the court, and each case seems to go on its own facts. as an appeal to the exercise of that discretion. The scope of the applications for such declarations which the courts have approved, and the corresponding limitations upon the remedial possibilities in American practice, may be roughly shown under the following heads, merely as a means of convenient presentation.

I. A declaration of rights may be had where there is a present possibility of immediately creating a cause of action, as by a demand or refusal, but the parties have not done so, perhaps through reluctance to precipitate a conflict. This is the typical case for a friendly application to the court. It avoids the necessity of formal hostilities, such as American friendly suits require, and enables

$28(1916) 2$ Ch. 527 .

27 (1916) 2 Ch. 544.

29 (1916) 2 Ch. 587 .

2 In re Thomas (I916), 2 Ch. 331.

so In re Timson (1916), 2 Ch. 362.

31 In re Smith (1916), 2 Ch. 368.

33 In re Forrest (1916), 2 Ch. 386.

33 Schwann จ. Cotton (1916), 2 Ch. 459. 
the parties to show on the face of the record that there has been a forbearance of any peremptory action. Thus, while an action on a contract, either for specific performance or damages, requires the allegation and proof of a breach by the defendant, a declaration of rights would seem to be available without any such allegation.

In Williams, Hollins \& Co., Lim., v. Paget ${ }^{34}$ defendant was a manager employed by the plaintiff, under a salary and a contract for additional compensation equal to $5 \%$ of any excess earned over and above full preferred dividends of $5 \%$ and common dividends of $7 \%$. In I9I5 the company made profits in excess of the prewar standard, so that an excess profits tax became payable under the Finance Act. The question then arose whether the manager's additional compensation should be estimated before or after the deduction of the excess profits tax. Instead of creating a cause of action for damages by a demand on the part of the manager for compensation on the higher basis of computation, the parties obtained a declaration from the court as to the true basis.

In Rawlinson v. Mort ${ }^{35}$ the court made a declaration that a certain organ, which had come rightfully into the possession of the defendants, was the property of the plaintiff, although no demand for it had ever been made upon the defendants.

In $H$. Newsum \& Co., Lim., v. Bradley, ${ }^{36}$ the plaintiffs were indorsees of bills of lading for the carriage of a cargo of wood in defendant's steamship Jupiter from Archangel to Hull. The ship was torpedoed by a German submarine, and the crew were compelled by the enemy to leave her. Subsequently she was towed into a Scottish port by a British patrol boat, and the plaintiffs claimed the right to take possession of the goods without payment of freight. The parties agreed to allow the ship to proceed with her cargo to Hull subject to plaintiff's rights as of the date when she lay in the Scottish port, and this action was commenced for a declaration by the court as tô what those rights were, no demand or refusal appearing to have been made. The declaration was given as asked by the plaintiffs.

An extremely large and varied class of cases of this kind arises out of the construction of written instruments, fixing the mutual rights of parties. Here present claims for relief might be created through action by one party hostile to the rights asserted by another party, but under Order 54A, Rule $I$, such a course is rendered entirely unnecessary. A doubt having arisen as to the meaning or

\footnotetext{
34 (I917) 86 L. J. Ch. 287.

ss (x905) 93 L. T. 555 .

34 (1917) 86 L. J. K. B. 1238.
} 
effect of the instrument, this is enough to make it possible for any party concerned to present to the court the question upon which the doubt hinges.

A typical case is Cyclists' Touring Club v. Hopkinson, ${ }^{37}$ where certain members of the plaintiff club desired to grant a pension to the club's secretary, who had filled that office for many years. A minority voted against the pension. The question was raised whether under the articles of association such action would be valid, and this action was brought solely to determine the question of power under the articles, no action having been take nor threatened pursuant to the vote to grant the pension. The court declared that the granting of such a pension would not be ultra vires.

In $\operatorname{Re} S m i t h^{38}$ the plaintiffs asked the court to declare that by virtue of a certain contract made by them with one Smith, in his lifetime, they were entitled to have Smith's executors execute to them a legal mortgage upon certain property belonging to the estate as security for certain advances. The declaration was made.

Similar instances might be indefinitely multiplied, but the principle underlying them is plain and seems to call for no further illustraction. American practice limits bills for instructions to cases where there is some independent ground of equitable jurisdiction, such as trusts. ${ }^{30}$

2. Where one party only has a present right of action for legal or equitable relief, but the other will suffer a serious prejudice by delay in bringing it into court, the latter may have a declaration of rights.

Under American practice the courts can give the latter party no relief. He must helplessly wait until the party who has the cause of action chooses to sue him, even though the delay serves only to pile up the damages which he may eventually have to pay.

For example, suppose A claims that $B$ is infringing his patent. $B$ has a cause of action of the conventional type, but $A$ has not. $\dot{B}$ can sue $A$ but $A$ cannot sue $B$. $B$ may have a large investment in the machinery for making the disputed device, and may have spent large sums in advertising it. Upon B's assertion of patent rights $A$ must either discard his machinery, abandon his investment, and lose the good will be has built up, or continue to operate under the constant threat of an action for damages whenever $A$ thinks that sufficiently large damages have accrued to make a law suit a profitable venture. If a declaration of rights could be had,

\footnotetext{
st (1909) sor L. T. 848.

os (1916) 2 Ch. 206.

32 I Whitehouse Equity, Sec. 129.
} 
the manufacturer could at once apply for a determination of the validity of the asserted patent, and thus save himself from the risk of serious loss and injury.

Such was the case presented in North Eastern Marine Engineering Co. v. Leeds Forge Co., ${ }^{40}$ where defendants claimed that plaintiffs were infringing their patents. Plaintiffs asked for a declaration that defendants' patents were invalid and that plaintiffs had not invaded any of defendants' legal rights. The court held that the giving of declaratory judgments was discretionary, and that in this case there was an adequate remedy provided by the PATENTS, Designs and Trademarks Acr, namely, a petition for the revocation of the patent, hence no declaration would be made. But in the court of appeal, upon a showing that such a petition had already been presented, but leave to file it had been refused for the probable reason that the patent had expired, a declaration was made that the mere fact of the expiration of the patent was not sufficient to justify the Attorney-General in refusing permission to file a petition for revocation. The whole course of reasoning of the court sustains the conclusion that if the plaintiff had been without any other remedy, as of course he would have been in the United States, ${ }^{11}$ a declaration of rights as requested might have been made.

Another common instance of such a situation occurs where one makes separate contracts with two other parties, and one or each of the latter claims that his contract is broken by the contract with the other, as where two jobbers each claim exclusive rights in the same territory under separate contracts with the manufacturer. Here the manufacturer has no present cause of action for relief, and can only wait until sued by one or both of the jobbers. This situation is always possible where contemporary contracts are made with different persons respecting the same subject matter. Provision for declarations of rights would offer a satisfactory solution and would merely put into force the equitable rule of mutuality of remedy.

3. Where the plaintiff has no ground for relief but there is a probability, though not a threat, that the defendant may assert rights hostile to him, a declaration of rights may be had.

In Hopkinson v. Mortimer, Harley \& Co.42 plaintiff was the owner of full paid shares in defendant company. The company added a provision to their articles that the lien and right of for-

(Ig06) I Ch. 324.

12 The remedy offered under American practice is limited to a finding upon conflicting patents. U. S. R. S., Sec. 4918.

is (1917) 86 L. J. Ch. 467 . 
feiture which it had always had on part paid shares for debts due the company should be extended to full paid shares. The company disclaimed any intention of exercising this power. The plaintiff asked for a declaration that his full paid shares were not subject to forfeiture. It was held that this was a proper declaration and not premature, as his rights were invaded by the mere passage of the resolution.

4. Where a cause of action for relief is in a condition which might be called inchoate, and lapse of time is necessary to perfect it, the court will declare the rights of the parties. ${ }^{43}$

In Austen v. Collins ${ }^{44}$ a will created a life estate with successive remainders, with the proviso that if any devisee should refuse or neglect for one year to take and bear the surname and arms of Austen, then the devise should terminate, and the property should at once go to the person next in remainder. The plaintiff was the life tenant, and after the College of Arms had refused him permission to use the arms required, and before the year had elapsed, he asked for a declaration that he had not forfeited his life estate. The declaration was made as asked.

In West v. Lord Sackville $e^{45}$ the plaintiff claimed that he was the lawful and eldest son of Lord Sackville, defendant, and was en-

4 Even before 1852 , when the first legislation authorized declaratory judgments in England, courts of chancery had sometimes undertaken to pronounce such judgments, England, courts of chancery had sometirregular. Thus, in Curtis v. Sheffield (1882), 23 and they were deemed only technically irregular. Thus, in Curtis v. Shefield (1882), 25 Ch. D. 1, it appeared that in made seren deciarations of right as to seven legacies giren by the will of the restaris. in the future after the deaths of the various tenants for life. Those declarations were in the future af all the children of the testator who were then living appear to have been of age, and they appeared by counsel and argued the various questions which were decided by the Court. Now it is true that it is not the practice of the Court, and was not the practice of the Court of Chancery, to decide as to future rights, but to wait until the event has happened, unless a present right depends on the decisions, or there are some other special circumstances to safisfy the Court that it is desirable at once to decide on the future rights. But where all the parties who in any event will be entitled to the property are of age and are ready to argue the case, the reason of the rule departs, and it becomes a bare technicality. The reason for the rule is this, that the Court will not decide on future rights, because until the event happens it does not know who may be interested in arguing the question, and therefore may be shutting out parties who, when the event happens, may be entitled to sueceed, but where they are all of age, and every possible party is represented before the Court, as I said before, utility seems to say that there should be a power to determine their rights, as is the case in Scotland and in many other countries."-Jessel, M. R.

The opinion proceeds to say that there probably were not any special circumstances in this case, because Vice-Chancellor Shadwell frequently disregarded the rale, but at most it was a technical irregularity, and the plaintiff, the surviving child, cannot now re-open the question, but is bound by the original declarations.

4 (1886) 54 L. T. 903.

45 (1903) 2 Ch. 378 . 
titled under a certain settlement to an estate in tail male, expectant on the decease of Lord Sackville, in the family estates. He alleged that he could not bring his claim to trial during the lifetime of Lord Sackville, and brought this action to perpetuate testimony as to his claims. This relief was denied, but STIRLING, J., suggested that in his opinion an action might have been brought under Order 25 , Rule 5 , for a declaration of his title to the estates as tenant in tail in remainder expectant on the death of his father.

In Powell \& Thomas v. Eivans Jones \& $\mathrm{Co}^{\star{ }^{*}}$ defendants filed a counterclaim against an agent for the portion of his commission which had already been paid to him, on the theory that he had received the same to defendants' use, and then asked for and obtained a declaration that he would become indebted to them for any further sums when and as he should receive them on account of said commission.

5. When the plaintiff has and can have no cause of action for relief, but his dealings with third persons depend on the determination of questions arising between himself and the defendant, a declaration of rights will be made.

In Jenkins v. Price, the lessee of a hotel wished to assign her lease, but under its terms could not do so without the lessor's consent, unless such consent was unreasonably refused. The lessor refused. The lessee, in order to place herself in a position where she could deal with her proposed assignee, asked for a declaration that the refusal was unreasonable and released her from the restriction against assignment. This declaration was given.

Another case very similar to the last is West v. Gwynne ${ }^{48}$ where a lease contained a condition against underletting unless with the consent of the lessor. Plaintiffs, who were lessees by assignment, asked permission to relet, but the lessor refused, except on condition that he should receive one-half the surplus rental the plaintiffs were to obtain. Plaintiffs, believing that this condition was invalid under the Conveyancing Acr, asked for a declaration to that effect, and the court so declared. ${ }^{90}$

Lord Justice VAUGHAN WIILIAMS, in a similar case ${ }^{50}$ used very strong language in support of the practice, saying:- $" * * *$ It seems to me that it would be quite shocking if the Court could not put an end to the dispute in the way the learned judge has done

\footnotetext{
40 (1905) I K. B. II.

$4(1907)=\mathrm{Ch}, 229$.

4 (IgII) $2 \mathrm{Ch}$. I.

- A similar declaration was made in Evans v. Levy (rgro, I Ch. 452.

so Young v. Ashley Gardens Properties, Lim. (Ig03), 2 Ch. Irz.
} 
by this order. I mean it would be quite shocking if $* * *$ the Court were bound to say, 'Although we have the whole matter before us $* * *$ we must leave matters in this state, that the landlord may continue to abstain from granting his license and the tenant must assign at his own risk-that is, at the risk of forfeiture'." And CozENS-HARDY, I. J., said in the same case, "I cannot imagine a more judicious or beneficial exercise of the jurisdiction to make a declaratory order than that which has been adopted by Joyce, J. in this case."

A similar situation arises in case of attempted sales of property in which others claim rights. The prospective purchaser does not care to buy a lawsuit, and only by a declaration of right against the claimant can the title be made merchantable in cases where a bill to quiet title would not lie.

Thus, in $R e$ Burroughs-Fowler,, 51 an antenuptial settlement conveyed real and personal property to trustees to sell the same and pay the rents, profits and income to the husband during his life or until he should be declared bankrupt or subject to certain other conditions. The husband was later adjudicated a bankrupt, and the trustee in bankruptcy offered this life interest of the bankrupt for sale, but the prospective purchaser objected that this life interest was defeasible. The trustee in bankruptcy thereupon applied for a declaration that he was able to convey a good title to an indefeasible life interest of the bankrupt, and the court so declared.

In $R e$ Trafford's Settled Estates ${ }^{52}$ the applicant wished to sell certain lands which he acquired under a will, freed from certain annuities which were created by the same will. He could do so only if he was a person having the powers of a tenant for life, and asked for a declaration that he had such powers. The court decided the question so presented.

6 . Where there is no present cause of action in the ordinary sense but the accrual of such a cause of action will subject the plaintiff to the risk of penalties, the court will declare the rights of the parties.

In such a case the plaintiff is not required to incur the risk of the penalties, but may obtain a declaration to inform himself of his rights in anticipation of penal liability. The question was thoroughly argued in a number of cases involving the inquisitorial powers of crown officers, and the judges all agreed that the anticipatory declaration of rights was an eminently suitable remedy.

\footnotetext{
a (1916) 2 Ch. 251 .

$\square$ (I9I5) I Ch. 9.
} 
Thus, in Burghes v. Attorney-General ${ }^{33}$ the Commissioners of internal revenue had required plaintiff to make certain returns respecting rents paid out or received, for the purpose of fixing duties on land values. . The plaintiff asked the court for a declaration that he was not bound to give the information demanded. WARRINGTON, J., said:

"It is contended that there is no cause of action against the Crown or its officers, that they have broken no contract and have done the plaintiff no legal wrong, nor do they threaten to do so. But Order 25 , r. 5 , is intended to deal with the very case-that is, one in which no relief can be claimed either by way of damages for the past or an injunction for the future, and, in fact, in several cases declarations have been made under this Order where there was no cause of action in the proper sense ***

"The complaint is that officers of the Crown are demanding information they are not entitled to, and, to say the least of it, reminding the subject of unpleasant consequences which may ensue if it is refused. It seems to me immaterial whether the terms of the notice amount to an actual threat; the reference to the penalty is plainly intended to intimate to the plaintiff that compliance can, and will, be compelled if necessary. If the question be not decided in this way it must be left open until the plaintiff, having refused to comply, is sued for penalties, and the plaintiff would be left in a position of great perplexity. In my opinion, the mode adopted by the plaintiff for obtaining a decision is a very convenient one, enabling the Commissioners to be informed how far they may go, and relieving the plaintiff from the doubt and perplexity into which he has been cast."

Another action of the same kind was brought in the King's Bench Division, and the Court of Appeal took the same view as WARRINGTON, J., in the Burghes case. This was Dyson v. Attorney-General, ${ }^{54}$ in which FARWFLL, L. J., speaking in the Court of Appeal, said:-

"It is obviously a question of the greatest importance; more than eight millions of Form IV [the form on which the information was required to be given] have been sent out in England, and the questions asked entail much trouble and in many cases considerable expense in answering; it would be a blot on our system of law and procedure if there is no way by which a decision on the true limit of the power of inquisition vested in the Commissioners can be obtained by any member of the public aggrieved, without putting him-

(I9II) 3 Ch. I39, I55.

* (I9II) I K. B. 4I0, 421 ff. 
self in the invidious position of being sued for a penalty $* * *$ The next argument on the Attorney-General's behalf was ' $a b$ inconvenienti'; it was said that if an action of this sort would lie there would be innumerable actions for declarations as to the meaning of numerous Acts, adding greatly to the labours of the law officers. But the Court is not bound to make declaratory orders and would refuse to do so unless in proper cases, and would punish with costs persons who might bring unnecessary actions: there is no substance in the apprehension, but if inconvenience is a legitimate consideration at all, the convenience in the public interest is all in favour of providing a speedy and easy access to the Courts for any of His Majesty's subjects who have any real cause of complaint against the exercise of statutory powers by Government departments and Governemnt officials, having regard to their growing tendency to claim the right to act without regard to legal principles and without appeal to any Court $* * *$ If ministerial responsibility were more than the mere shadow of a name, the matter would be less important, but as it is, the Courts are the only. defence of the liberty of the subject against departmental aggression."

And still later, in Dyson v. Attorney-General, ${ }^{50}$ the Court of Appeal repeated the same views very strongly, FrETCHER MourToN, L. J., saying: "*** I think that an action thus framed is the most convenient method of enabling the subject to test the justifiability of proceedings on the part of permanent officials purporting to act under statutory provisions."

7. Where plaintiff as a strict matter of law, has a right to an injunction, yet on account of the peculiar facts of the case the court may prefer to substitute a declaration of right as a more suitable remedy.

In Vestry of St. Mary, Islington v. Hornsey Urban District Coun$c i l^{58}$, the plaintiffs, a metropolitan vestry, agreed to allow defendants, a district outside the metropolitan area, to discharge their sewage into plaintiffs' sewer, but after many years operation it was found that this additional sewage periodically stopped up plaintiffs' sewer. 'The agreement was ultra iires and void. The plaintiffs sought an injunction to restrain defendants from discharging sewage into plaintiffs' sewers. It was held that while the court had power to grant the injunction, yet, in view of the difficulty in which it would place defendants if obliged to close

es (1912) I Ch. $158,168$.

(1900) I Ch. 695 . 
sewers in daily use, the Court would only make a declaration establishing plaintiff's right to relief, to give defendants time to make other arrangements, with leave to apply for an injunction after the expiration of a reasonable time.

In Llandulno Urban District Council v. Woods, ${ }^{57}$ the plaintiffs were the local authority of Llandudno, and the seashore at that point between high and low watermark was vested in them under a lease from the Crown. Defendant was a clergyman of the Church of England, and asked permission to hold religious services on the beach. Plaintiffs refused, but the defendant held them notwithstanding. The plaintiff asked a declaration that defendant was not entitled to make addresses or hold meetings on the shore at Llandudno without their consent, and an injunction. It was held that since the plaintiffs possess the legal right to prohibit anyone from coming upon the shore, the declaration asked will have to be given, but the matter is too trivial to merit the use of an injunction.

8. Where relief can only be granted in a foreign jurisdiction, the respective rights of the parties may be fixed by a declaration as an aid to the foreign adjudication.

In The Manar, ${ }^{58}$ the plaintiffs were mortgagees of the British ship Manar, and on default in payment of the mortgage they had taken possession and chartered the ship for a voyage to France. On arrival there the defendants, Strachan Brothers, British subjects, arrested the ship and freight, claiming as creditors of the mortgagors for necessaries furnished to the ship. It appeared to be in dispute whether the French court would apply the English law in determining whether the plaintiffs as mortgagees or the defendants as necessaries men were entitled to the possession of the ship and freight. The plaintiffs asked for a declaration that they were entitled to the ship and freight as against defendants. It was held that since it was not clear from the evidence what effect a judgment in this action would have in France, and since it had not been shown that the declaration sought would not be of practical utility to plaintiffs in the French Court, the declaration would be given.

It seems quite evident that England has far surpassed this country in devising remedial methods calculated to make the courts useful and available under the exacting requirements of modern

7 (1899) = Ch. 705.

(1903) P. 95. 
civilization. We have canonized the ancient tradition of a cause of action, in all its original crudeness, and have made it the condition and the measure of judicial action. We have failed utterly to see the enormous and far-reaching possibilities in preventive relief,-prevention not merely of threatened wrongs but prevention of uncertainty and misunderstanding in the assertion of rights. Yet here is an effective, workable system, tried out under conditions identical with those in our own country, which marks an advance over previous doctrines comparable to the great reform which equity made over the harsh rules of the common law. Its use would entail no reconstruction of our judicial machinery, no readjustment of other elements in our remedial system.

Its theory and operation are prefectly simple. By adopting the language of the English rules, Order 25, Rule 5, authorizing declarations of rights, and the supplementary, though possibly unnecessary, rule, Order $54 \mathrm{~A}$, Rule I, authorizing the judicial construction of documents, we might enjoy the fruits of England's experience, enriched as it is by the thirty-five years' labor which her courts have devoted to charting the waters over which the applicant for a declaratory judgment must sail.

EIDSON R. SUNDERLAND.

The Law School,

University of Michigan. 